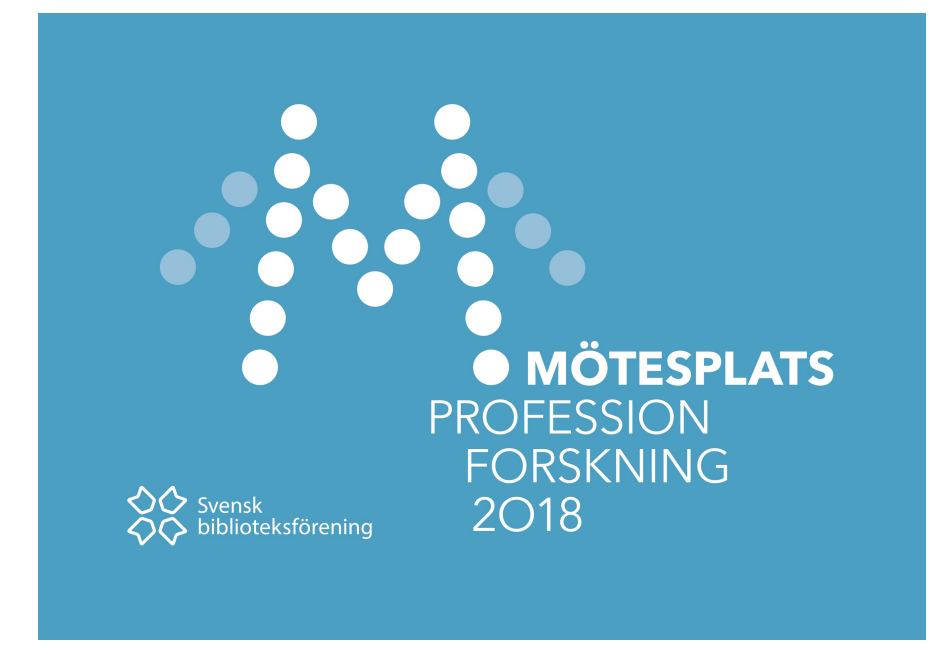

Annika Lindqvist \& Ulla-Carin Stenberg

Arvika bibliotek

annika.lindqvist@arvika.se

ullacarin.stenberg@arvika.se

\title{
Valet är ditt (Att höja utlandsföddas valdeltagande, HUVA)
}

\section{Bakgrund/Problemformulering}

Upprinnelsen till projektet är en debattartikel i Dagens Nyheter den 6 september 2017, med rubriken "Lågt valdeltagande bland utlandsfödda hotar demokratin". Artikelförfattarna Pieter Bevelander och Mikael Spång hänvisade till en rapport från Delmi (Delegationen för migrationsforskning). Rapporten har titeln "Valdeltagande och Representation. Om invandring och politisk integration i Sverige" och berör det faktum att utlandsföddas svaga politiska integration har hamnat i skymundan i diskussionen om integration.

Rapporten, och debattartikeln, ger exempel på det svaga deltagandet i det politiska systemet: I riksdagsvalet 2014 röstade närmare 90 procent av de inrikes födda, men bara 75 procent av de röstberättigade som är födda utomlands.

Valdeltagande ger en fingervisning om hur inkluderad man känner sig i samhället samt hur man ser på de egna möjligheterna till påverkan. Själva handlingen att gå till valurnan bör vara resultatet av en process.

Utrikesfödda är på intet sätt en enhetlig grupp. Lägst är valdeltagandet bland dem som är födda i Asien, Afrika och i europeiska länder utanför Norden. Merparten av dem som nu invandrar till Sverige kommer från dessa områden, vilket pekar på att valdeltagandet kan komma att sjunka ytterligare i framtiden.

I Sverige finns också en allt större grupp utrikesfödda som ännu inte är (och kanske aldrig väljer att bli) svenska medborgare. Den som har varit folkbokförd i landet i mer än tre år har inte rätt att rösta i riksdagsvalet, men väl till kommun och landsting.

Där är det demokratiska underskottet ännu större. Endast var tredje utländsk medborgare utnyttjade sin rätt att rösta i primärkommunala och landstingskommunala val. Ett på sikt ännu mer oroande faktum är att också barn till utlandsfödda röstar i lägre utsträckning än barn till svenskfödda. 
Gruppen utlandsfödda och barn till utlandsfödda har växt snabbt i Sverige. Om trenden med lågt valdeltagande och generellt dålig politisk integration fortsätter bland stora grupper i samhället är det risk att demokratins grundvalar skakas.

\section{Bibliotekets uppdrag}

Biblioteken har möjlighet och skyldighet att vara en positiv kraft som kan förse människor med underlag och kunskaper så att de känner till och kan utöva sina demokratiska rättigheter, så vill man i korthet gärna tolka bibliotekets uppdrag.

Uppdraget har alltid varit livligt debatterat och beskrivet i olika sammanhang. För knappt 20 år sedan kom den lilla skriften Bibliotek - mötesplats i tid och rum som diskuterar hur det demokratiska uppdraget ska konkretiseras och hur det bör förändras i takt med samhällsomvandlingen ${ }^{1}$

Bibliotekslagen ${ }^{2}$ betonar bibliotekens betydelse för det demokratiska samhällets utveckling och den grundläggande roll de spelar för kunskapsförmedling och fri åsiktsbildning. Lagen knyter på så sätt an till hur bibliotekens grundläggande uppdrag uttryckts i internationella sammanhang, till exempel i IFLA:s och Unesco:s olika biblioteksmanifest. ${ }^{3}$

I arbetet med en nationell biblioteksstrategi presenterades den 13 september 2017 en omvärldsrapport. ${ }^{4}$ I denna rapport presenterar Johan Hirschfeldt ${ }^{5}$ en imponerande genomgång av 2 § i bibliotekslagen där varje ändamålsformulering tolkas och kopplas samman med grundlagarna. Han skriver bl.a.:

Grunden för det allmännas stöd till biblioteksväsendet står att finna $i$ övertygelsen om att bibliotekens verksamhet bidrar till en önskad samhällsutveckling i stort och att demokratin befästs och fördjupas genom att välinformerade individer får bättre möjligheter till insyn, inflytande och deltagande i den demokratiska processen. (...) Att biblioteken ska verka för det demokratiska samhällets utveckling uttrycker en målsättning om allas delaktighet i samhällslivet som främjas genom de medel som nämns, det vill säga kunskapsförmedling och fri åsiktsbildning.

I samma rapport skriver redaktörerna i slutordet:

\footnotetext{
${ }^{1}$ Bibliotek - mötesplats i tid och rum (2000)

2 Bibliotekslag (2013:801)

${ }^{3}$ Bibliotekens internationella manifest (2014) Svensk biblioteksförening och Svenska Unescorådet

${ }^{4}$ Den femte statsmakten : bibliotekens roll för demokrati, utbildning, tillgänglighet och digitalisering (2017)

${ }^{5}$ Hirschfeldt, Johan (2017). "Biblioteken - en femte funktion i den demokratiska rättsstaten". Den femte statsmakten : bibliotekens roll för demokrati, utbildning, tillgänglighet och digitalisering. Red. Erik Fichtelius m.fl. sid. 67-85
} 
2017 är demokratin hotad av auktoritära och högerextrema krafter i Europa och USA.(...)

Samtidigt befinner sig medier runt om i världen i kris, och det blir därför också demokratins kris. Det hoppfulla är att förekomsten av "alternativa fakta" och falska nyheter väcker motkrafter till liv. Utredningen om en nationell biblioteksstrategi hävdar att bibliotekens roll för att försvara det demokratiska samtalet och en åsiktsbildning byggd på både fakta och pluralism är central.

Peter Alsbjer presenterade på sin blogg en fallstudie som Arts Council i England genomfört, sex berättelser om mångfald och inkludering på bibliotek. Där visar resultatet bland annat att de mest framgångsrika biblioteksverksamheterna är de som kopplar ihop sina aktiviteter med övergripande nationella, regionala och lokala politiska prioriteringar samt att arbetet på det fysiska biblioteket lika väl som bibliotekens uppsökande verksamhet och partnerskapsarbete är avgörande. Forskningen har visat på fördelar för biblioteken att bygga starka partnerskap med lokalsamhället och samhällsorganisationer för att kunna svara mot samhällets behov.

Vi har haft $2 \S$ i bibliotekslagen som en ledstjärna:

2 § Biblioteken i det allmänna biblioteksväsendet ska verka för det demokratiska samhällets utveckling genom att bidra till kunskapsförmedling och fri åsiktsbildning.

Biblioteken i det allmänna biblioteksväsendet ska främja litteraturens ställning och intresset för bildning, upplysning, utbildning och forskning samt kulturell verksamhet i övrigt.

Biblioteksverksamhet ska finnas tillgänglig för alla

\section{Metod}

Mot bakgrund av tolkningen av demokratiuppdraget bestämde sig Arvika bibliotek för att fånga bollen och starta en utveckling av verksamheten med syfte att öka utlandsföddas kunskaper om och deltagande i demokratin samt att göra detta i nära samverkan med andra kommunala förvaltningar, politiken och organisationer som till exempel Hyresgästföreningen och studieförbunden.

Arvika bibliotek sökte och fick 100000 kr i utvecklingsbidrag från Svensk biblioteksförening och $150000 \mathrm{kr}$ från Arvika kommun. Biblioteket ville pröva att utveckla en metod för samhällsinkludering i en folkbibliotekskontext. Vi önskade även positionera biblioteksverksamheten och skapa ett hållbart partnerskap mellan olika kommunala enheter, politiken och föreningslivet.

Avsikten med projektet var att skapa ett forum för samhällsinformation där vi med inslag av utbildning ville arbeta med olika typer av kompetenser, t.ex. källkritik, mediekunskap och propaganda kopplad till digital kompetens, kännedom om svensk demokratis utveckling samt förmedla insikt om hur vår välfärd hänger ihop med vilka politiska partier som har majoriteten. Vi ville även arbeta med att öka deltagarnas språkliga kunskaper för att höja deras förmåga att ta till sig och värdera information.

\footnotetext{
${ }^{6}$ https://peterals.wordpress.com/2018/08/09/sex-berattelser-om-mangfald-och-inkludering-pa-bibliotek-uk/
} 
Ursprungsidén var att skapa fyra-fem block som skulle löpa hela tiden under januariseptember 2018, där deltagare skulle kunna ansluta sig under projektperioden.

De tänkta blocken var följande:

Arvika kommun som demokratiskt/politiskt styrd organisation. Rättigheter och skyldigheter som medborgare.

Tjänstepersoner presenterar de olika kommunala verksamheterna.

Deltagande demokrati, representativ demokrati. Partierna presenterar sig och berättar om sitt arbete och sina visioner.

Demokratins utveckling i Sverige, inklusive skönlitterära skildringar. Författarmedverkan. Källkritik, medier. Medverkan av journalister.

Biblioteket anlitade frilansjournalisten Annika Lindqvist som projektledare. Aktiviteterna i projektet diskuterades fram i en projektgrupp bestående av representanter från biblioteket, integrationscentrum, SFI, studieförbundet NBV, kommunens valsamordnare, och kommunikationsavdelning samt kommunfullmäktiges ordförande.

Målgruppen avgränsades inledningsvis till att omfatta utlandsfödda personer som blivit svenska medborgare de senaste fyra åren och som är bosatta i Arvika.

Vi började arbetet i januari 2018 med att skriva ett personligt brev till alla personer $\mathrm{i}$ målgruppen:

Du är en av de Arvikabor som har blivit svenska medborgare de senaste åren.

Så roligt att du valt att bli medborgare! Det betyder bland annat att du i höst för första gången har rätt att rösta i valet till Sveriges riksdag. Du får också vara med och bestämma vilka politiker som ska styra i Arvika kommun och i Värmland.

Inför valet den 9 september satsar Arvika bibliotek extra mycket på att berätta om hur de offentliga verksamheterna fungerar, och prata om på vilka sätt vi invånare kan påverka vad som sker.

Vi ska bland annat ha träffar med kommunens anställda som berättar om sådant som sjukvård, skola, äldreomsorg och kommunala bostäder.

Vill du vara med? Du får också möjlighet att träffa politiker och diskutera det som är bra och mindre bra i kommunen, du fär veta mer om hur den svenska demokratin har utvecklats och du får diskutera med andra.

Biblioteket kommer att bjuda in till en serie föreläsningar på temat Valet är ditt. Den första hålls redan på torsdag den 18 januari kl 18. Då kommer författaren och läsfrämjaren Torgny Karnstedt. Under rubriken Orden som blir fönster mot världen pratar han om vad språket och berättarkonsten betyder för vår förmåga att förstå vår samtid och omvärld.

Listan över de Arvikabor över 18 år som blivit svenska medborgare sedan valet 2014 och fram till 2017-11-10 omfattar 209 namn. 
De är en mycket heterogen grupp, både i ålder, ursprungsland och etablering i det svenska samhället. Rätt många kommer från Norge eller Danmark och har bott i decennier i Sverige innan de bestämt sig för att bli medborgare.

Det första utskicket gav endast få napp. En handfull personer hörde av sig och ville ha information om de kommande aktiviteterna. Några av dem kom till den första föreläsningen.

Snabbt kände vi att gruppen nyblivna svenska medborgare var för svår att nå, just eftersom den är så spretig. Det finns ingen naturlig mötesplats för att träffa dem, och deras behov av information är mycket skiftande.

Därefter har vi skickat riktad information om föreläsningar, kulturgrupper etc, enbart till dem bland de nya svenska medborgarna som anmälde sitt intresse.

Vid ytterligare ett tillfälle skrev vi brev till dem som blev svenska medborgare under 2017 och som välkomnades till en medborgarskapsceremoni på nationaldagen den 6 juni. I brevet underströk vi på nytt rätten att rösta den 9 september och bjöd in till två utfrågningar av de politiska partierna som hölls i slutet av maj.

Fokus kom att ligga på dem som är mer nyanlända, framförallt för att vi bedömde att det är de som har störst behov av information.

Vi bytte också namn på projektet från "Att höja utlandsföddas valdeltagande i Arvika, HUVA", som det hette i bidragsansökan till Svensk biblioteksförening och Arvika kommun, till "Valet är ditt", för att det var betydligt lättare och trevligare att använda på affischer och annat.

\section{Intervjuundersökning Sweden Research}

Ett erbjudande från Sweden Research om att intervjua kommuninvånare som har rätt att rösta i primärkommunala och landstingskommunala val, men inte i riksdagsvalet, passade väldigt väl in i våra planer. Det gäller invånare som har varit mantalsskrivna i Sverige i minst tre år, men som inte blivit svenska medborgare.

Den 18 december gjorde Carlos Rojas från Sweden Research två olika gruppintervjuer med sammanlagt elva personer ur målgruppen på Arvika bibliotek. (Rapporten med namnet "Här i Sverige finns det demokrati. Vi trodde inte att det fanns, men det finns. Utländska medborgare om att rösta 2018" bifogas)

De intervjuade kom från Syrien, Somalia, Rumänien, Syrien/Palestina och Holland.

Urvalet av intervjupersoner blev knappast representativt för hela gruppen. Vi ställde frågan om att delta till personer som vi känner eller känner till och som är intresserade av att delta i samhället - men svaren var ändå intressanta.

Alla utom en säger att de tror att de kommer att rösta i september.

På frågan om vilket ämne som är viktigast för dem i valet ger de ett brett spektrum av svar: allt från kortare arbetstid till polisbrist och bättre villkor för företagande. Dock återkommer möjligheter till arbete och jämlika arbetsvillkor bland de nämnda viktiga valfrågorna.

Alla ville att politikerna skulle föra mer samtal direkt med invånarna, och bli bättre på att integrera de utlandsfödda i sina plattformar. 


\section{Föreläsningar och studiecirklar/studiegrupper}

Under första hälften av våren 2018 presenterades ett antal föreläsare inom de områden vi ville fokusera på.

Först ut var författaren och läsfrämjaren Torgny Karnstedt.

Därefter framträdde stand-up-poeten Daniel Boyacioglu under rubriken "Det språk vi talar blir den kropp vi bär". Kopplat till dessa båda föreläsningar om språkets betydelse började biblioteket arbeta med tre olika läsgrupper med nyanlända.

En grupp bestod av syriska män som nått den svenska pensionsåldern och två bestod av elever på svenska för invandrare, SFI.

En annan aktivitet som startade efter dessa båda författares framträdande var en skrivarcirkel i ABF's regi med temat "Gör din röst hörd" där deltagarna främst ägnade sig åt poesi/sångtexter.

Journalisten Sarah Delshad från idéplattformen Muslimska feminister höll en föreläsning. Mahmoud Agha, grundare och ägare till mediahuset Alkompis som förmedlar nyheter om Sverige och det svenska samhället på arabiska höll en annan föreläsning.

Viralgranskaren Åsa Larsson föreläste om källkritik. Kopplat till föreläsningarna om medier bildades en liten studiegrupp som diskuterade journalistik och källkritik.

Syftet med studiegruppen ligger helt i linje med bibliotekens ansvar att, förutom att ge invånarna fysisk tillgång till medier, också ge invånarna intellektuell tillgång till medier. ${ }^{7}$ När lite mer än en månad återstod till valet höll vi den första valskolan i projektets regi. Valskola är en orientering om hur det rent praktiskt går till att rösta.

De sista veckorna före valet planerar vi upprepade valskolor på biblioteket i samarbete med studieförbundet NBV.

Dagen före valet, den 8 september, gästar Arabiska teatern biblioteket med en dockteaterföreställning. Vi tror att detta är ett bra tillfälle att nå framförallt arabisktalande kvinnor och kommer att se till att det finns lättillgänglig information om valet till medföljande mammor och andra vuxna.

\section{Välbesökta föreläsningar}

Samtliga föreläsningar hölls på biblioteket och var som helhet välbesökta. Generellt nådde vi både dem som brukar komma på bibliotekets evenemang, och nya grupper. Genom intensiv marknadsföring på SFI, det kommunala Integrationscentrum och till de båda syriska föreningar som verkar i Arvika fick vi ovanligt stora grupper nyanlända att komma på föreläsningarna.

\section{Politikers medverkan}

De som Sweden Research intervjuade lyfte fram vikten av att politiker vänder sig till utlandsfödda och berättar om valet och sina partiprogram. Sweden Research visade också att i valet 2014 var det endast 28,7 procent av Värmlands utlandsfödda som utnyttjade sin

\footnotetext{
${ }^{7}$ Människorna, medierna och marknaden. Medieutredningens forskningsantologi om en demokrati i förändring/SOU 2016:30. Folkbiblioteken i medielandskapet (sid 515-538)
} 
rätt att rösta i valen till kommuner och landstinget, och att den siffran har sjunkit sedan 2002 (31,9 procent). ${ }^{8}$

Pieter Bevelander och Mikael Spång uttrycker det så här i den debattartikel som blev fröet till hela projektet: Med tanke på det parlamentariska läget borde underskottet på röstande med utländsk bakgrund uppfattas som en enorm potential av de politiska partierna.

Det understryker vikten av att också politikerna är genuint intresserade av att inlemma de nya invånarna i det demokratiska arbetet.

Ledamöterna i kommunfullmäktige fick, tillsammans med dem som särskilt arbetar med integration i Arvika, en egen föreläsning.

Journalisten och författaren Karin Alfredsson, talade om "Framgångsrecept för en lyckad integration". Hon utgick från sin rapport "Vägar till effektivare integration", ${ }^{9}$ som hon skrivit på uppdrag av tankesmedjan Global utmaning. Rapporten bygger på besök i en handfull, sinsemellan olika, svenska kommuner som lyckats anmärkningsvärt väl med att få utlandsfödda i sysselsättning.

I slutet av maj hölls en utfrågning av kommunala partier i Dottevik, en stadsdel där många utlandsfödda bor, och en "speed-dejting" på biblioteket, där invånarna fick prata och ställa frågor direkt till politikerna.

Den 6 augusti hölls också en "politisk picknick i parken" då de lokala politikerna presenterade sina respektive program från scenen i Stadsparken, varvat med teater för barn och vuxna och musik. Picknicken i parken hölls samma dag som demokratiminister Alice Bah Kuhnke gästade Arvika och projektets valskola för utlandsfödda på det kommunala Integrationscentrum. Närmare 40 utlandsfödda (många av dem SFI-studerande) besökte valskolan, och det mediala genomslaget för evenemanget var stort.

De förtroendevalda har deltagit i projektets aktiviteter med entusiasm och har uppskattat att få plattformar för att nå grupper som de generellt sett når i alldeles för liten utsträckning.

\section{Politiskt styrd verksamhet}

Kopplingen mellan offentlig verksamhet och politik är höljd i dunkel för många, även infödda svenskar. Projektets intention har varit att tydliggöra att offentlig verksamhet såsom barnomsorg, tillgång till boende, skola och föreningsverksamhet är politiskt styrda och att man kan påverka satsningar och prioriteringar genom sitt engagemang i politik/föreningsliv och genom sin röst.

Projektet har i samverkan med integrationscentrum presenterat olika kommunala verksamheter. Dessa presentationer har varit framgångsrika och öppnat upp för många frågor. Tjänstepersoner har då berättat om sina respektive verksamheter, samtidigt som integrationscentrums språkvärdar har kunnat översätta till arabiska, somaliska och tigrinja. Samma presentationer har i vissa fall hållits i forum som till exempel bibliotekets språkcaféer och studieförbundet NBV:s studiegrupper för arabiskspråkiga.

Också kommunalt anställda och landstingsanställda har med glädje tagit möjligheten att få förklara och ibland reda ut vanliga missuppfattningar.

\footnotetext{
8 "Min röst kan betyda något" - Utländska medborgare om att rösta 2018, rapport från Sweden Research

${ }^{9}$ Alfredsson, Karin (2017): Vägar till effektivare integration. Rapport från tankesmedjan Global Utmaning
} 


\section{Resultat, svårigheter och glädjeämnen}

\section{Att nå målgruppen.}

Vi har kunnat starta alla de studiecirklar/kulturgrupper som vi planerade, men det har varit få deltagare.

Här ska vi också notera att många av dem som vi HAR nått inte har rösträtt till några svenska politiska församlingar under 2018. Stora grupper har visserligen varit i Sverige i mer än tre år, men på grund av långa handläggningstider hos Migrationsverket inte fått uppehållstillstånd så snabbt att de blir röstberättigade 2018.

Vi har bortsett från det, dvs vi har informerat också dem som inte får rösta i höst, och resonerat utifrån att kunskapen om demokrati är nyttig hursomhelst.

Ett ännu tydligare exempel på att vi aktivt har sökt upp utlandsfödda som inte har rösträtt är att vi till firandet av Internationella Kvinnodagen 8 mars engagerade Monirah Hashemi, Karlstadsbaserad skådespelare och pjäsförfattare, och att vi då bjöd in ensamkommande ungdomar som bodde på eller hade bott på kommunens HVB-hem, där många precis som Monirah Hashemi är hazarer med ursprung i Afghanistan.

Även när vi vände oss till en bredare målgrupp än den vi från början definierade har vi haft svårt att locka målgruppen.

Vi hade säkert kunnat vara bättre på att rikta marknadsföringen mer effektivt till dem vi vill nå, och vi hade behövt planera verksamheten tydligare i samarbete med dem det berör. Till exempel hade det varit bra att ta paus i aktiviteterna under ramadan och istället intensifierat verksamheten under juli då många i vår målgrupp finns kvar i stan, men då svenskfödda i allmänhet har semester.

Bättre kännedom om målgruppen hade underlättat.

På så sätt blev projektet för oss en påminnelse om att det inte enbart är utlandsfödda som har bristfällig information om det svenska samhället - svenska offentliganställda har i allmänhet också för lite kunskap om stora grupper invånare i Sverige.

Det ska dock understrykas att vi har haft stor hjälp av täta kontakter med en syriskfödd verksamhetsutvecklare på NBV, som organiserar verksamhet för nyanlända och som har ingått i projektets referensgrupp.

Språket är ett mycket stort hinder. För de allra flesta tar det lång tid att erövra så goda kunskaper i ett nytt språk att man kan tillgodogöra sig politisk information.

Kampen för att få vardagen att fungera är också krävande för många, och ett eventuellt politiskt engagemang är inte högst prioriterat.

Det som har fungerat bäst är informationstillfällena på Integrationscentrum, med tillgång till översättare till arabiska, somaliska, tigrinja. Vi har tagit fasta på de områden som engagerar folk mest (bostäder, barnomsorg, äldreomsorg, familjerätt) och fått stort intresse.

Målsättningen har varit att samarbeta också med SFI så att eleverna får tillgodoräkna sig mötena som lektionstid i samhällsinformation, men det har inte alltid fungerat. SFI:s regler, som i sin tur bygger på de gränser som arbetsförmedlingen sätter upp, har ibland varit för stelbenta. 


\section{Bibliotekets position i den kommunala förvaltningen}

Kommunledningen har varit kontinuerligt informerad. Projektledaren har informerat om projektet på ett fullmäktigesammanträde och på ett frukostmöte med kommunledningsstaben.

Bibliotekets verksamhet har genom projektet blivit synliggjord och positionerad.

\section{Slutsatser}

För goda resultat behöver man använda sig av redan etablerade mötesplatser. Att bygga upp nya är betydligt svårare. Biblioteket är en naturlig samlingspunkt, Integrationscentrum är det också. NBV:s grupper för arabiskspråkiga på söndagar är ytterligare en etablerad mötesplats.

\section{Efterspel}

Vi räknar inte med en mätbar ökning i valdeltagandet i höstens val, men vi hoppas att politiker och tjänstepersoner ska vilja bygga vidare på det som har fungerat bra. Vi har lyckats bygga en infrastruktur för samverkan över förvaltningsgränser kring integrations- och demokratifrågor. Förhoppningsvis kommer det att leva sitt eget liv och fortsätta också efter att valet är över och projektet avslutat.

Motivationen till att organisera sig och påverka samhället uppstår då man inser att denna möjlighet kan leda till positiv förändring, valdeltagandet kommer då som ett naturligt resultat.

I allra bästa fall kommer det att finnas ett aktivt intresse, såväl från utlandsfödda potentiella väljare och politiskt engagerade som från politiska partiföreträdare, att öka deltagandet och fördjupa demokratin - även om det är fyra år kvar till nästa val. 


\section{Käll- och litteraturförteckning}

Alfredsson, Karin (2017) Vägar till effektivare integration: Goda integrationsexempel från Svenska kommuner. Stockholm: Tankesmedjan Global utmaning. Hämtad 20 april 2018, från: https://www.globalutmaning.se/wpcontent/uploads/sites/8/2017/11/Forstudie Alfredsson slutvers webb.pdf

Atlestam, Ingrid \& Myhre, Randi (red.) (2012) Det mångspråkiga biblioteket: en nödvändig utopi. Lund: Btj förlag.

Atlestam, Ingrid \& Forsén, Ulla (red.) (2010) Där människor och tankar möts: bibliotek som folkbildning. Lund: Btj förlag.

Bevelander, Pieter (2017) "Lågt valdeltagande bland utlandsfödda hotar demokratin". Dagens Nyheter, 5 september, s. 5.

Bibliotekens arbete med nyanlända. (2016). Stockholm: Svensk Biblioteksförening. Hämtad den 16 augusti 2018, från: https://www.biblioteksforeningen.se/wpcontent/uploads/2017/01/nyanlanda-webb.pdf

Bibliotekens internationella manifest. (2014). Stockholm: Svensk biblioteksförening. Hämtad den 16 augusti 2018, från: https://www.biblioteksforeningen.se/wp-

content/uploads/2017/01/bibliotekens-internationella-manifest-webb-utskrift.pdf

Biblioteket som noder för samhällsutveckling i samverkan. (2016). Mötesplats för Social Innovation. Malmö Högskola. Hämtad 1 augusti 2018, från: http://socialinnovation.se/wpcontent/uploads/2016/11/Co Lab1 Bibliotek och Samverkan.pdf

Biblioteksbladets tema "Plats för nyanlända". Hämtad 16 augusti 2018, från: http://biblioteksbladet.se/integrationen-startar-pa-biblioteket/

Brisander, Cecilia. (2017). Bibliotek i samspel med lokalsamhället. Stockholm: Regionbibliotek Stockholm.

Delmi (2017:7). Bevelander, Pieter \& Spång, Mikael (red.) Valdeltagande och representation - Om invandring och politisk integration i Sverige. Stockholm: Delegationen för migrationsstudier.

Fichtelius, Erik m.fl. (red.) (2017). Den femte statsmakten: Bibliotekens roll för demokrati, utbildning, tillgänglighet och digitalisering. Stockholm: Kungliga biblioteket/Nationell biblioteksstrategi. Tillgänglig på internet:

http://nationellbiblioteksstrategi.blogg.kb.se/files/2017/09/Den femte statsmakten WEBB VERSION.pdf

Jones, Nick (2012). Försök att förstå: folkbibliotek, rasism och platsens politik. Lund: BTJ förlag. 
Pilerot, Ola \& Hultgren, Frances (2017). Folkbibliotekens arbete för och med nyanlända. Uppsala, Länsbibliotek Uppsala. Tillgänglig på internet:

http://www.lul.se/Global/Kultur/L\%C3\%A4nsbibliotek\%20Uppsala/Projekt/Dokument/L\%C3 \%A4nsbibl arbete nyanl\%C3\%A4nda webb.pdf

Rojas, Carlos (2015) Biblioteket hjälper mig att komma in i samhället. Regionbibliotek Stockholm. Hämtad 6 augusti 2018, från: http://regionbiblioteket.se/wpcontent/uploads/2015/12/miklorapportBibliotekethjalperdigslutver2.pdf

Rojas, Carlos (2018) "Min röst kan betyda något" -Utländska medborgare om att rösta 2018 : Insikter från intervjuer med 43 utländska medborgare i tre svenska kommuner. Stockhom: Sweden Research. Hämtad 16 april 2018, från:

http://files.swedenresearch.com/reports/UtlandskaMedborgareOchValet2018-

PDF rapport hela.pdf

SAB:s demokratigrupp (red.) (2000) Bibliotek - mötesplats i tid och rum: en bok om demokrati. Lund: Btj förlag.

SFS 2013:801. Bibliotekslag. Stockholm: Kulturdepartementet. 